\title{
Genetic Diversity of Diazotrophs Nodulating Pigeon Pea in Arid and Semi-Arid Zones of Haryana, India
}

\author{
Kuldeep Singh*, Subha Dhull and Rajesh Gera \\ Department of Microbiology, Chaudhary Charan Singh Haryana Agricultural University, \\ Hisar-125004, Haryana, India \\ *Corresponding author
}

\section{A B S T R A C T}

Keywords

Pigeon pea,

Diversity, Rhizobia, nifH, Dendrogram, Biotypes

Article Info

Accepted:

26 February 2018

Available Online:

10 March 2018
The genetic diversity within forty nine rhizobial strains isolated from root nodules of pigeon pea crop grown in pots holding $5 \mathrm{~kg}$ soils collected from arid and semiarid zones of Haryana, India was investigated by using PCR-RFLP of the ribosomal operon [16S rRNA gene] and 16S rRNA gene partial sequence analysis. Genomic DNA of these rhizobial isolates was tested for $\operatorname{nod} \mathrm{C}$ and nifH gene primers and hence authenticated as rhizobia. Out of 49 rhizobial isolates, only 35 isolates showed nifH gene amplification by using two different set of primers. All rhizobial isolates were also amplified with 16S rDNA gene using $27 \mathrm{~F}$ and $1378 \mathrm{R}$ primers. The amplified product was subjected to RFLP analysis using MspI and HaeIII restriction enzymes. Dendrogram based on 16S rDNA profiles using ARDRA, showed 18 different biotypes at $80 \%$ similarity coefficient. Most prevalent biotype was $13^{\text {th }}$ type, which prevails in all the four studied districts. Geographical origin and soil properties are defining feature for rhizobial diversity, which group them into separate genotypes. These results may be important in formulating rhizobial inoculants specific for pigeon pea under arid and semi-arid zones for agriculture development.

\section{Introduction}

Biological nitrogen fixation (BNF) is the symbiotic association of legumes and $\mathrm{N}_{2}-$ fixing microorganisms that converts atmospheric elemental nitrogen $\left(\mathrm{N}_{2}\right)$ into ammonia $\left(\mathrm{NH}_{3}\right)$ by nitrogenase in rhizobial bacteroids and accounts for $65 \%$ of the nitrogen presently used in agriculture (Matiru and Dakora, 2004). Sustainable agriculture involves successful management of agricultural resources to satisfy the changing human needs, while enhancing and retaining the environmental quality as well as preserving the natural resources. Consequently, sustainability rumination demanded an alternate to nitrogenous fertilizers. In this context, biological nitrogen fixation offered an alternate farming practice as it exploits the capacity of certain nitrogenfixing bacteria to reduce atmospheric nitrogen in to ammonia mediated by the enzyme nitrogenase (Burris and Roberts, 1993; Hardson and Atkins, 2003; Darnajoux et al., 2017). Owing to the series of interactions between leguminous plants and rhizobia nodules are formed by the bacteria called as nodule promoting rhizobacteria (NPR) or 
PGPR (plant growth promoting rhizobacteria) which thrive in the interior of the plant cells, confined within specialized structures (Gray and Smith, 2005). Nitrogen fixation is,time and again, restricted when the natural populace of rhizobia is futile in encouraging high crop yields. Therefore, extensive research is planned to improve the efficiency of the symbiosis as a result of economical significance of the Rhizobium-legume association.

One-third of the earth's surface is under arid and semi-arid climate which hindered the crops production due to high soil temperatures, higher soluble salts and high $\mathrm{pH}$ in these areas (Kayasth et al., 2014a, b; Kumar et al., 2014; Kumar and Gera, 2014). The rhizobial strains from arid and semi-arid regions are acclimatized to such unfavourable environmental conditions and might be effective inoculant strains for crops growing under hostile conditions (Zahran 2001; Mnasri et al., 2007; Gera et al., 2014; Kumar et al., 2014; Mondal et al., 2017b). Therefore, it is imperative to replace the existing rhizobia by bringing in more effective strains, which is possible only if the inoculum strain can beeffectively against indigenous rhizobia.

Pigeon pea [Cajanus cajan (L.) Millspaugh] is grown in semi-arid tropics in Asia and Africa and belongs to family Fabaceae. Being versatile, stress-tolerant and nutritious grain legume and possessing characteristics of value for improving the sustainability of dry subtropical and tropical agricultural systems (Khoury et al., 2015) it is the favoured pulse crop in dryland areas where it is intercropped or grown in mixed cropping systems with cereals or other short duration annual crops (Joshi et al., 2001; Kepner et al., 1987; Anonymous, 2011). It also increases soil fertility through nitrogen fixation as well as from the leaf fall and recycling of the nutrients (Snapp et al., 2002; Mapfumes, 1993). Cajanus cajan (L.) Millsp. (Pigeon pea) is commonly nodulated by the cowpea miscellany group of rhizobia thatare indigenous to tropical soils. Genetic analysis of rhizobia has led to identification of nod genes, which are required in the control of host specificity, infection and nodulation. Both the type and the amount of nod factors are essential in deciding host specificity. Yet, rhizobia which have different nod genes and produce distinctive nod factors can efficiently nodulate the same plant (Poupot et al., 1993, 1995). Using the comparison of the nod C and nif $\mathrm{H}$ as molecular markers and $16 \mathrm{~S}$ rRNA phylogenies, significant correlation between symbiotic genotypes and host plant groups can be ascertained (Laguerre et al., 2001).

Diversity is a vital aspect for genetic characterization with unique nitrogen fixing capacities. The current studies disclose that there is wide diversity at the genus, species and intra-species levels. Dudeja and Nidhi (2014) ascertained that there are 16 genera of bacteria which are capable toform nodules in different legumes. For instance, Rhizobium, Ensifer, Mesorhizobium, Phyllobacterium, Bradyrhizobium, Ochrobactrum, Methylobacterium, Azorhizobium, Allorhizobium, Aminobacter, Shinella and Devosia belonging to $\alpha$-proteobacteria and four genera, Burkholderia, Microvirga, Cupriavidus and Herbaspirillum belonging to $\beta$-proteobacteria.

About 120 species belonging to these genera form nodules in different legumes. These genera are phylogenetically distinct from each other based on $16 \mathrm{~S}$ rDNA sequences, but the rhizobia do not form a coherent group as they are amalgamated with other non-symbiotic bacteria (Young and Haukka, 1996). Today, nearly $14,11,6,5,5,4,3$ and 2 species have been described that are capable of nodulating common bean, soybean, cowpea, chickpea, peanut, lentils, faba bean and pea, respectively (Shamseldin et al., 2017). On the basis of the $16 S$ ribosomal DNA sequence, the currently described legume's symbionts belong to three 
major distinct phylogenetic subclasses: $\alpha, \beta$ and $\gamma$-Proteobacteria and 238 species were grouped into 18 genera and two clades (Shamseldin et al., 2017).

Differentiation of rhizobia into strains, species and sub-species reckons upon the methodology being used. Nowadays, more attention has been focused on molecular methods that complement the traditional microbiological procedures adopted for identifying and studying heterogeneity (Wu and Traanksley, 1993; Muyzer and Smalla, 1998; Muyzer, 1999). The availability of sensitive, easy, rapid, reliable and accurate PCR-based genotyping among closely related bacterial strains and the detection of higher rhizobial diversity have been greatly considered (Vinuesa et al., 1998; Josic et al., 2002; El-Fiki, 2006; Rajasundari et al., 2009; Gera et al., 2014). The study of the rhizobial ecology and diversity is intended at exploring one of the most precious biological resources and continuous attempts are being made to discover novel bacterial strains to boost the agricultural productivity (Rao, 2013; Ansari and Rao, 2014). In present study, the rhizobial isolates were isolated from root nodules of Pigeon pea and thenthe genomic DNA was amplified for nod $\mathrm{C}$, nifH and 16S rDNAgene. PCR-RFLP of the 16S rDNA gene to study their genetic diversity and phylogenetic relationships in arid and semi-arid zones of Haryana was established.

\section{Materials and Methods}

Physico-chemical properties of soil samples collected from arid and semi-arid zones of Haryana

It is essential to ensure the chemical properties of the soil samples as they influence the growth and nutrient uptake of the plants. A total of 84 soil samples were collected in sterile plastic bags from therhizosphere of pigeon pea crops fields from different village of four districts (Hisar, Bhiwani, Mahendergarh and Rewari) of Haryana. The samples were transported to the laboratory and stored at $4^{\circ} \mathrm{C}$ before analyses. Electrical conductivity (EC) of the samples was calculated in soil-water saturated extracts prepared by added $12.5 \mathrm{~mL}$ of distilled water to $5 \mathrm{~g}$ of soil. After shaking for $10 \mathrm{~min}$, the samples were kept for the night until the soil settled. EC measurements were recorded in the supernatant by an EC meter. The samples were also analysed for $\mathrm{pH}$ according to Conyers and Davey (1988), organic C according to Kalembasa and Jenkinson (1973), and total $\mathrm{N}$ by the method of Kjeldahl.

\section{Rhizobial strains}

Rhizobia were isolated from naturally occurring root nodules of pigeon pea plant growing either in the field or under greenhouse conditions in soil samples from arid and semi-arid zones of south-Western Haryana, India. After rinsing in $95 \%$ ethanol, nodules were surface sterilized using $0.1 \%$ acidified mercuric chloride (Vincent, 1970), squashed in $0.2 \mathrm{ml}$ sterile water, and then streaked onto yeast extract mannitol agar (YEMA) plates. The inoculated plates were incubated at $28 \pm 2{ }^{\circ} \mathrm{C}$ for $24-48 \mathrm{~h}$ and observed for specific features of rhizobia. Single colonies of Rhizobia were isolated and maintained separately on YEMA slants at $4^{\circ} \mathrm{C}$ for further study.

\section{DNA isolation for genotypic characterization}

Genomic DNA was extracted from bacteria by using CTAB method. For the isolation of genomic DNA, the rhizobia were separately grown in tryptone yeast extract (TY) broth. The bacterial pellets were washed with $50 \mathrm{Mm}$ ethylene diaminetetraacetic acid (EDTA, pH 8.5). The washed cells were lysed by 
suspending in $0.5 \%$ sodium dodecylsulphate (SDS) for $10 \mathrm{~min}$ at $60^{\circ} \mathrm{C}$. The resulting lysate was cleared from cell debris by centrifugation at $10,000 \mathrm{rpm}$ for $10 \mathrm{~min}$. The supernatant was taken and protein was removed by adding proteinase $\mathrm{K}$ followed by addition of ethanol to collect the DNA. The DNA solution was prepared by the addition of $1 \mathrm{ml}$ phenolchloroform mixture. RNase $\left(50 \mu \mathrm{g} \mathrm{ml}^{-1}\right)$ was added to DNA extract and mixture was incubated at $37^{\circ} \mathrm{C}$ for $30 \mathrm{~min}$. This was followed by the addition of tris-phenol and centrifugation at $12,000 \mathrm{rpm}$ for 15 to $20 \mathrm{~min}$ at $4^{\circ} \mathrm{C}$. Sodium acetate $(0.3 \mathrm{M}) 100 \mu \mathrm{l}$ and cold isopropanol $(1 \mathrm{ml})$ were added with continuous vortex to the heat sterilized supernatant. The DNA was purified by the addition of phenol-chloroform followed by centrifugation at $15000 \mathrm{rpm}$ (Sambrook and Russel, 2001). Finally, the DNA contained in water was stored at $-20^{\circ} \mathrm{C}$ in deep freezer. The concentration and purity of DNA was assessed by measuring A260/A280 ratio; A260:A280 = 1.5-1.8 for pure DNA. Purity of DNA was also checked on $0.8 \%$ agarose gel and bands were observed. In case of faint or no bands, DNA extraction was repeated.

\section{Amplification of nodC sequences (Laguerre et al., 2001)}

PCR reaction mixture was used for amplification of nod C sequences. Amplification of nod $\mathrm{C}$ sequences was carried out by polymerase chain reaction (PCR) using a thermal cycler. The primer $\mathrm{CI}$ and $\mathrm{CF}$ enables the amplification of nod $\mathrm{C}$ sequences present in rhizobial DNA. The amplification reaction was performed in $24.0 \mu \mathrm{l}$ volume per reaction. The reaction mixture was prepared by using the mixture of taq polymerase and dNTP's. The reaction conditions for PCR were: Initial denaturation at $95^{\circ} \mathrm{C}$ for $3 \mathrm{~min}$. folowed by 30 cycles of denaturation at $94^{\circ} \mathrm{C}$, annealing at $54.4^{\circ} \mathrm{C}$ for $1 \mathrm{~min}$., extension at $72^{\circ} \mathrm{C}$ for $2 \mathrm{~min}$. with final extension of 3 minutes at $72^{\circ} \mathrm{C}$ and holding at $4^{\circ} \mathrm{C}$. Amplified gene was visualized in $0.8 \%$ agarose after electrophoresis (Kumar et al., 2006). The prokaryotic specific primers used for amplification of nod $\mathrm{C}$ sequences were:nod $\mathrm{C}-\operatorname{nod} \mathrm{CF}-\left(5^{\prime}\right.$ - AYG THG TYG AYG ACG GTT C- 3'); nod CF2- (5'- AYG THG TYG AYG ACG GCT C -3'); nod CF4- (5'AYG THG TYG AYG ACG GAT C -3'); nod CFn- (5'- AGG TGG TYG AYG ACG GTT C -3'); nod CI- (5'- CGY GAC AGC CAN TCK CTA TTG - 3').

\section{Amplification of nifH sequences (Ueda et al., 1995 and Perret and Broughtn, 1998)}

Amplification of nif $\mathrm{H}$ sequences was carried out by PCR using a thermal cycler with PCR reaction mixture. Two sets of primers nif $19 \mathrm{~F}$, nif407R (Ueda et al., 1995) and nifH1, nifH2 (Perret and Broughtn, 1998) enables the amplification of nifH sequences present in rhizobial DNA. The amplification reaction was performed in $24.0 \mu \mathrm{l}$ volume per reaction. The reaction mixture was prepared by using the mixture of taq polymerase and dNTP's.

DNA amplification was carried out with the following PCR conditions:-Initial denaturation at $95^{\circ} \mathrm{C}$ for $4 \mathrm{~min}$., denaturation at $94^{\circ} \mathrm{C}$ for 30 Sec., annealing at $55^{\circ} \mathrm{C}$ for $1 \mathrm{~min}$., extension at $72^{\circ} \mathrm{C}$ for $1 \mathrm{~min}$., repeat steps 2 to 4 at least 40 times with final extension at $72^{\circ} \mathrm{C}$ for 5 min. and holding at $4^{\circ} \mathrm{C}$. An aliquot of $10 \mu \mathrm{l}$ of amplified product was visualized on $1.2 \%$ agarose gel after electrophoresis. Visualization was captured on a gel documentation system. The prokaryotic specific primers used for nif $\mathrm{H}$ gene amplification were:-nifH - nif $19 \mathrm{~F}-\left(5^{\prime}\right.$ GCI WTY TAY GGI AAR GGI GG - 3'); nif 407R- (5'- AAI CCR CCR CAI ACI ACR TC - 3'); nifH1- (5'-CGT TTT ACG GCA AGG GCG GTA TCG GCA- 3'); nifH2- (5'-TCC TCC AGC TCC TCC ATG GTG ATC GG$\left.3^{6}\right)$. 
16S rRNA gene amplification (Lukow et al., 2000)

Polymerase chain reaction (PCR) using a thermal cycler with PCR reaction mixturefor amplification of $16 \mathrm{~S}$ rDNA sequences was carried out. The primers $27 \mathrm{~F}$ and 1378R enables the amplification of 16S rDNA sequences present in rhizobial DNA. The amplification reaction was performed in 50.0 $\mu \mathrm{l}$ volume per reaction. The conditions for 16SrDNA sequences gene amplification was the same as those used for $\operatorname{nod} \mathrm{C}$ and $n i f \mathrm{H}$ amplification, except that the annealing steps took place at $60^{\circ} \mathrm{C}$ and the extension periods were $2 \mathrm{~min}$. in each cycle. The prokaryotic specific primers used for $16 \mathrm{~S}$ rRNA gene amplification were:-16S rDNA-27 F-(5'AGA GTT TGA TCC TGG CTC AG 3');1378 R- (5'- CGG TGT GTA CAA GGC CCG GGA ACG - 3').

\section{PCR-RFLP of the 16S rDNA gene}

Restriction fragment length polymorphism (RFLP) is the identification of specific restriction patterns that reveal the difference between the DNA fragment sizes in individual organisms. In RFLP analysis, different restriction enzymes are used to cut DNA at specific sites. DNA sample was cut with individual restriction enzyme separately and resulting fragments were separated using gel eletrophoresis according to their molecular size. In present work, two restriction enzymes MspI and HaeIII were used for RFLP analysis with $16 \mathrm{~S}$ rDNA product. For the digestion, 10 $\mu \mathrm{l}$ of amplified $16 \mathrm{~S}$ rDNA product was treated with $1 \mu \mathrm{l}$ of both the enzymes separately and held on constant $37^{\circ} \mathrm{C}$ for $12 \mathrm{~h}$ in thermal cycler. The restriction fragments were separated by horizontal electrophoresis in TBE buffer [ $89 \mathrm{mM}$ Tris, $89 \mathrm{mM}$ boric acid, 2 mM EDTA (pH 8.0)] with a $2 \%$ (wt./vol.) agarose gel containing $1 \mathrm{mg}$ of ethidium bromide per $\mathrm{ml}$. The gels were run at $80 \mathrm{~V}$ for
$3 \mathrm{~h}$ and immediately photographed with geldog (Acer C200, Azure Biosynthesis) with a 320-nm UV source. During separation of the fragments by agarose gel electrophoresis, the smaller fragments (100 bp or less) appeared diffuse and therefore were not used in the RFLP analysis.

\section{Gel electrophoresis}

Genomic DNA was resolved by using $0.8 \%$ agarose gel in TBE buffer and $2 \%$ agarose gels was used for analysis of amplification of the PCR products and for analysis of PCR products were digested with two restriction enzymes, respectively. DNA $(5 \mu 1)$ was mixed with $3 \mu \mathrm{l}$ of loading dye and loaded in the well. The gel was run at $80 \mathrm{~V}$ for 30-45 min. The gel was stained with ethidium bromide and finally visualized under UV light in Gel documentation system. 100 and 1000bp DNA ladder were used as the marker DNA.

\section{Phylogenetic analysis}

To elucidate the taxonomic positions of the isolates, we partially sequenced the $16 \mathrm{~S}$ rRNA genes of 49 rhizobial strains representing the various $16 \mathrm{~S}$ rRNA PCR-RFLP genotypes. The aligned sequences of the pigeon pea rhizobia were used in the phylogenetic analysis. In scoring only reproducible bands were scored. The size of each band was compared with the standard marker and the profiles of the isolates were made.

Depending on presence or absence of a particular band, 0-1 matrix was prepared. Similarity matrices were constructed following SimQual Coefficient and were analyzed by UPGMA (unweighted pair grouping with mathematic average) was used to align the sequences and phylogenetic trees were constructed using the neighbour-joining method in NTSYS-PC program (version 2.1: Exeter Software, Setauket, N.Y.) (Rohlf, 
1998). Dendrogram were constructed from the genetic similarity between different rhizobia by the UPGMA.

\section{Genbank accession numbers}

The 16S rDNA gene sequences of the rhizobial strains were deposited in the National Center for Biotechnology Information (NCBI) GenBank database and accession number obtained (Table 3). Nearest identities of the strains were obtained by comparing sequences of the isolated 16SrRNA gene with available sequences in GenBank (http://www.ncbi.nlm.nih.gov/) using the BLASTn program.

\section{Results and Discussion}

Physico-chemical properties of soil samples collected from arid and semi-arid zones of Haryana

The physico-chemical properties $(\mathrm{pH}, \mathrm{EC}$, organic $\mathrm{C}$, and total $\mathrm{N}$ ) of 84 rhizospheric soil samples are shown in Table 1. As evident from the data, the soil samples differed notably in their physico-chemical properties, which were possible to affect the plant growth and nodulation by rhizobia. The $\mathrm{pH}$ of the soil samples ranged from 6.7 (Hisar district) to 8.5 (Bhiwani and Mahendergarh district). The EC was lowest $\left(0.07 \mathrm{dS} \mathrm{m}^{-1}\right)$ in Hisar soil but highest $\left(0.67 \mathrm{dS} \mathrm{m}^{-1}\right)$ in Bhiwani soil. Organic carbon content varied from 0.15 (Bhiwani) to $0.67 \%$ (Mahendergarh), whereas total $\mathrm{N}$ ranged from 80 (Bhiwani) to 145 (Mahendergarh) $\mathrm{kg} \mathrm{ha}^{-1}$.

Out of these, the nodule formation was observed only in 82 pots and after 45 days of germination resulted in nodule formation on the roots of these plants. In total 196 rhizobial isolates were obtained out of which 28 isolates were obtained from Hisar, 79 from Bhiwani, 73 from Mahendergarh and 16 isolates were obtained from Rewari districts. Out of 196 pigeon pea rhizobial isolates, only 23 isolates showed growth in the peptone broth indicating the doubt about their authenticity. The failure to nodulate by the remaining soil samples might be due to either the total absence or only small number of efficient rhizobia in these samples or their adverse physicochemical characteristics. For above purpose, soil and nodule samples were tried to be collected from pigeon pea field from different villages of Haryana State because of the poor nodulation in fields due to environmental conditions like high temperature, water stress and other factors dependent on the host plant and the invading microsymbiont Rhizobium, there was very poor nodulation in the field crops. Therefore, soil samples were collected to trap pigeon pea rhizobia under pot house conditions.

\section{Rhizobial strains}

Forty nine pigeon pea rhizobia was selected as described previously (Kuldeep et al., 2016) from naturally occurring root nodules of pigeon pea plant growing either in the field or under greenhouse conditions in soil samples from arid and semi-arid zones of southWestern Haryana, India. Similarly, Dhull and Gera (2017) isolated 158 rhizobial strains from clusterbean grown in semiarid regions of Haryana, India.

Ali et al., (2009) also isolated 27 rhizobial isolates from Leucaena leucocephala, Tephrosia purpurea and Crotalaria medicaginea for screening their stress tolerating ability with contrast to environmental abiotic soil conditions commonly prevailing in arid and semiarid regions of Rajasthan. Similarly, Koskey et al., (2017) isolated 9 distinct groups of isolates from the root nodules of MAC 13 and MAC 64 climbing beans (Phaseolus vulgaris L.) grown during field trapping experiment in Eastern Kenya. 
DNA isolation for genotypic characterization

All the 49 pigeon pea rhizobial isolates were grown in TY broth and incubated in flasks at $30^{\circ} \mathrm{C}$ for 2-3 days under shaking conditions to obtain log phase grown cells. DNA was isolated from all the isolates by using CTAB method for the amplification of nod $\mathrm{C}$, nif $\mathrm{H}$ and $16 \mathrm{~S}$ rDNA gene. The amount of DNA isolated from each isolate was approximately 70-100 ng $\mu \mathrm{l}^{-1}$. The isolated DNA was resolved on $0.8 \%$ agarose gel. Genomic DNA of few rhizobial isolates has been shown in Figure 1. Similarly Berrada et al., (2012) isolated genomic DNA using CTAB method of rhizobial isolates for molecular study.

\section{Amplification of nod $\mathrm{C}$ gene from genomic DNA}

To check the authenticity of rhizobia amplification of $\operatorname{nod} \mathrm{C}$ genes was done. The nod $\mathrm{C}$ gene fragments were amplified from all the 49 rhizobial isolates of pigeon pea (Figure 2) by using a forward primer nod $\mathrm{CF}$ and a reverse primer nod CI with specific PCR conditions.

The PCR product was resolved on $2 \%$ agarose gel to confirm the amplification and as expected a band of 930bp representing nod $\mathrm{C}$ gene product was obtained. The genomic DNA of all 49 rhizobial isolates was also tried with three other sets of primers but did not amplified.

Similarly, Laguerre et al., (2001) used the nod $\mathrm{C}$ gene, a common nod gene essential for nodulation in all rhizobial species, to characterize a collection of 83 rhizobial strains which represented 23 recognized species distributed in the genera Rhizobium, Sinorhizobium, Mesorhizobium and Bradyrhizobium. Nod C was used as one of the markers for investigation of common genomic traits in all $\alpha$-proteobacterial sequenced genomes using orthologos-species detection approach in biometric analysis (Pini et al., 2011). Similarly, Silva et al., (2012) reported that all 35 isolates belonged to the $\beta$ proteobacterium Cupriavidus necator possessed the nod $\mathrm{C}$ genes.

\section{Amplification of nif $\mathrm{H}$ gene from genomic DNA}

The highly conserved nature of nif $\mathrm{H}$ gene makes it an ideal molecular tool to determine the potential for biological nitrogen fixation in different environments (Zehr and Capone 1996). The genomic DNA of all the 49 pigeon pea rhizobial isolates was amplified with a forward primer nifH $19 \mathrm{~F}$ and a reverse primer nif407R (Ueda et al., 1995) to check the nitrogen fixation property of pigeon pea rhizobial isolates. Out of 49 isolates, only 8 showed nif $\mathrm{H}$ gene amplification with these primers and amplified product was of 390bp, whereas genomic DNA of 27 pigeon pea rhizobial isolates was amplified with another set of nifH gene primers i.e. nifH1 and nif $\mathrm{H} 2$ as described by Perret and Broughtn (1998) which resulted in a product size of $781 \mathrm{bp}$ (Figure 3). The rest of 14 isolates could not amplified with any of the nif $\mathrm{H}$ gene primers with varied PCR conditions. The PCR product was resolved on $2 \%$ agarose gel to confirm the amplification of nifH gene. Olivieri and Frank (1994) also reported that the rhizobia which are able to form nodules were not able to fix nitrogen or amplify nifH gene.

Similar results are reported by Dubey et al., (2010) where nitrogen fixation and nodulation abilities of Sinorhizobium strains (KCC1 to KCC8) were confirmed by amplification of $n i f \mathrm{H}$ gene to assess the diversity of rhizobial populations in pigeon pea growing in central part of India. Gera et al., (2014) also reported that out of 64 isolates of Vicia faba only 50 showed nif $\mathrm{H}$ gene amplification. 


\section{Amplification of 16S rDNA gene from genomic DNA}

The 16S rDNA is used to detect the similarity, since it is a highly conserved sequence. The size of $16 \mathrm{~S}$ rDNA is smaller than 23S rDNA and larger than the 5S rDNA, that is why it easy to handle. Most of the rhizobial diversity studies were carried out on the basis of nod C and $n i f \mathrm{H}$ genes but results obtained from $16 \mathrm{~S}$ rDNA were better than nod $\mathrm{C}$ and nif $\mathrm{H}$ genes. To study the diversity on the basis of partial $16 \mathrm{~S}$ rDNA gene, the genomic DNA of all the 49 pigeon pea rhizobial isolates was amplified by PCR with a forward primer BAC $27 \mathrm{~F}$ and a reverse primer $\mathrm{BAC} 1378 \mathrm{R}$ using standard PCR amplification conditions. PCR product was resolved by agarose gel electrophoresis to confirm the amplification. A single band of approximately $1.4 \mathrm{~kb}$ size was amplified from all 49 nod $\mathrm{C}$ positive rhizobial isolates (Fig. 4).

Similar results are reported by Ansari et al., (2014) that there was conservation of $16 \mathrm{~S}$ rRNA gene sequences among rhizobia in various soybean growing areas and the evolution of native rhizobial strains among slow and fast growers.

Laranjo et al., (2001) also reported on diversity of chickpea rhizobia from Portugal and Madeira Island was assessed using 16S rRNA gene. Similar results are reported by Meyer et al., (2014) on three strains isolated from Lebeckia ambigua root nodules and authenticated on this host.

Based on the 16S rRNA gene sequence phylogeny, they were shown to belong to the genus Burkholderia. Helene et al., (2017) reported on two strains belonging to the genus Bradyrhizobium- SEMIA 6399 and SEMIA 6404-isolated from root nodules of Deguelia costata (syn. Lonchocarpus costatus), an important legume native to eastern Brazil. On sequences, 16S rRNA gene was highly conserved in members of the genus Bradyrhizobium.

\section{PCR-RFLP of the 16S rDNA gene}

The PCR products were individually restricted with endonucleases MspI and HaeIII. Cluster analysis of combined RFLP patterns revealed that all field isolates obtained from pigeon pea nodules significantly differed. The product size of different bands varied from $50 \mathrm{bp}$ to 900 bp (Fig. 5 and 6).

\section{Diversity of pigeon pea rhizobial isolates}

The diversity of pigeon pea rhizobial isolates nodulating pigeon pea, which was isolated from South-Western parts of Haryana, was studied by preparing the dendrogram from the banding pattern obtained with restriction enzymes MspI and HaeIII individually and in combination.

\section{Restriction fragment length polymorphism (RFLP) by using restriction enzyme MspI}

In this study, MspI restriction enzyme was used to digest the amplified 16S rDNA fragment, which resulted in polymorphic bands. The product size of different bands varied from 50bp to 900bp (Figure 5). The banding pattern obtained from the ARDRA with $M s p$ I restriction enzyme was analysed using the software NTSYS-PC program and dendrogram was constructed to show the grouping of various isolates (Figure 7). It was observed that all the isolates were present at the level of $72 \%$ similarity coefficient where it formed two major groups. Major group I was having all the isolates except PPH-4A, PPB-8, PPB-8B, PPH-8C, PPM-33B and PPM-37D which formed a separate group and were the members of major group II. Major group I was further divided in to two subgroups at $75 \%$ similarity coefficient. 
Table.1 Soil properties of the study area

\begin{tabular}{|l|c|c|}
\hline & Overall range & Methods \\
\hline pH & $6.7-8.5$ & $1: 2$ Soil:Water \\
\hline Electrical Conductivity $\left(\mathrm{dS} \mathrm{m}^{-1}\right)$ & $0.07-0.67$ & $1: 2$ Soil:Water \\
\hline Organic C $(\%)$ & $0.15-0.67$ & Kalembasa and Jenkinson $(1973)$ \\
\hline Total $\mathbf{N}\left(\mathrm{kg} \mathrm{ha}^{-1}\right)$ & $80-145$ & Kjeldahl Method \\
\hline
\end{tabular}

Table.2 Prevalence of rhizobial biotypes infecting pigeon pea in four districts of Haryana

\begin{tabular}{|c|c|c|c|}
\hline Biotype & Rhizobial isolates & $\%$ of isolates & Districts \\
\hline 1 & PPB-34D, PPB-37C and PPB-35A & $6.1 \%$ & Bhiwani \\
\hline 2 & PPB-33A & $2 \%$ & Bhiwani \\
\hline 3 & PPR-7B & $2 \%$ & Rewari \\
\hline 4 & PPR-2, PPB-34C and PPB-23B & $6.1 \%$ & Rewari, Bhiwani \\
\hline 5 & PPB-21B & $2 \%$ & Bhiwani \\
\hline 6 & PPH-2B and PPH-8C & $4 \%$ & Hisar \\
\hline 7 & PPM-30A & $2 \%$ & Mahendergarh \\
\hline 8 & PPB-22B, PPM-21B and PPB-25A & $6.1 \%$ & Bhiwani, Mahendergarh \\
\hline 9 & PPB-14 and PPM-21A & $4 \%$ & Bhiwani, Mahendergarh \\
\hline 10 & PPB-7A & $2 \%$ & Bhiwani \\
\hline 11 & PPB-22A & $2 \%$ & Bhiwani \\
\hline 12 & PPH-10B & $2 \%$ & Hisar \\
\hline 13 & PPH-4A, PPR-4B, PPB-38B and PPM-14 & $8.2 \%$ & Hisar, Rewari, Bhiwani, Mahendergarh \\
\hline 14 & PPM-22A & $2 \%$ & Mahendergarh \\
\hline 15 & PPB-8A & $2 \%$ & Bhiwani \\
\hline 16 & $\begin{array}{l}\text { PPH-9B, PPB-13, PPM-37A, PPB-3, PPH-10A, PPB-1, PPB- } \\
25 \mathrm{C} \text { and PPM-23A }\end{array}$ & $16.3 \%$ & Hisar, Bhiwani, Mahendergarh \\
\hline 17 & PPH-5A and PPH-8E & $4 \%$ & Hisar \\
\hline 18 & $\begin{array}{l}\text { PPH-1B, PPB-27B, PPB-30B, PPB-32C, PPH-2A, PPB-8, } \\
\text { PPB-8B, PPM-35A, PPB-26A, PPB-34B, PPH-8A, PPM-37D } \\
\text { and PPM-33B }\end{array}$ & $26.5 \%$ & Bhiwani, Hisar, Mahendergarh \\
\hline
\end{tabular}

Table.3 16S rRNA gene sequence similarity of pigeon pea rhizobial strains and their accession numbers

\begin{tabular}{|c|c|c|c|c|}
\hline Strain & Geographical origin & $\begin{array}{c}\text { Percent } \\
\text { Similarity }\end{array}$ & Isolate Name & $\begin{array}{c}\text { GenBank } \\
\text { 16S rRNA } \\
\text { gene accession } \\
\text { number }\end{array}$ \\
\hline PPB8B & Bhiwani, Haryana & 95 & Rhizobium sp. & KX531231 \\
\hline PPB25A & Bhiwani, Haryana & 99 & Rhizobium pursense & KX513930 \\
\hline PPH8C & Hisar, Haryana & 99 & Rhizobium pursense & KX531232 \\
\hline PPH10B & Hisar, Haryana & 99 & Rhizobium pursense & KX531230 \\
\hline PPM21A & $\begin{array}{l}\text { Mahendergarh, } \\
\text { Haryana }\end{array}$ & 99 & $\begin{array}{l}\text { Agrobacterium } \\
\text { tumifaciens }\end{array}$ & KX539547 \\
\hline PPM33B & $\begin{array}{l}\text { Mahendergarh, } \\
\text { Haryana }\end{array}$ & 99 & $\begin{array}{l}\text { Agrobacterium } \\
\text { tumifaciens }\end{array}$ & KX665589 \\
\hline PPM37D & $\begin{array}{l}\text { Mahendergarh, } \\
\text { Haryana }\end{array}$ & 99 & $\begin{array}{l}\text { Agrobacterium } \\
\text { tumifaciens }\end{array}$ & KX531228 \\
\hline PPR7B & Rewari, Haryana & 99 & Rhizobium pursense & KX539311 \\
\hline
\end{tabular}


Fig.1 Genomic DNA of rhizobial isolates isolated from nodules of pigeon pea plants

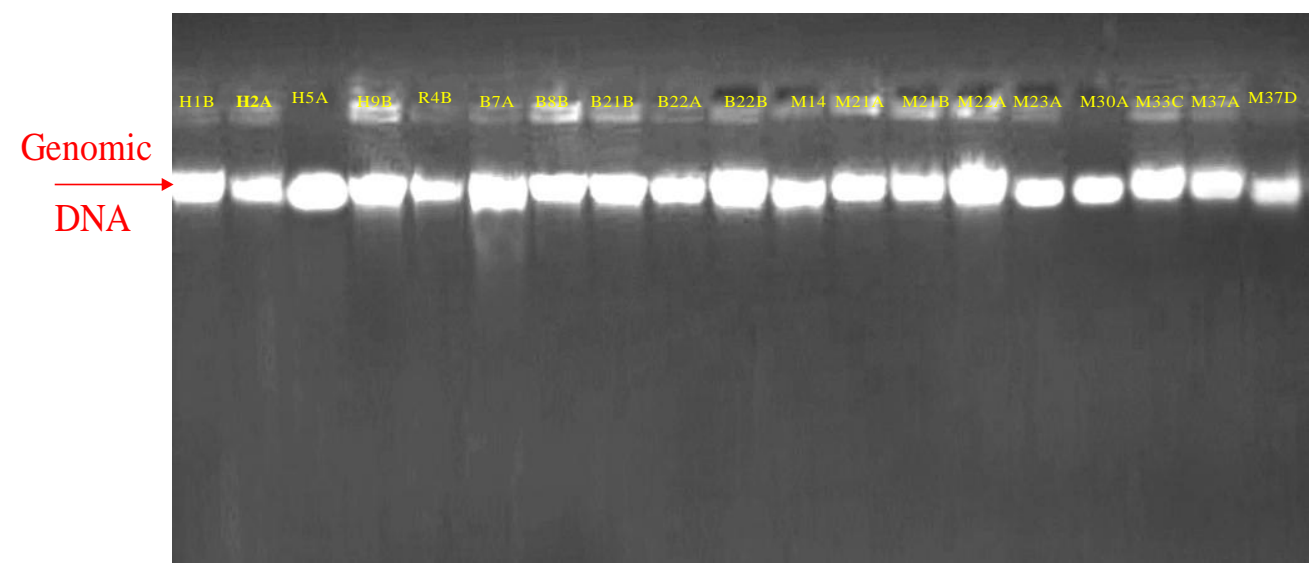

Fig.2 Amplification of nodC gene from genomic DNA of pigeon pea rhizobial isolates

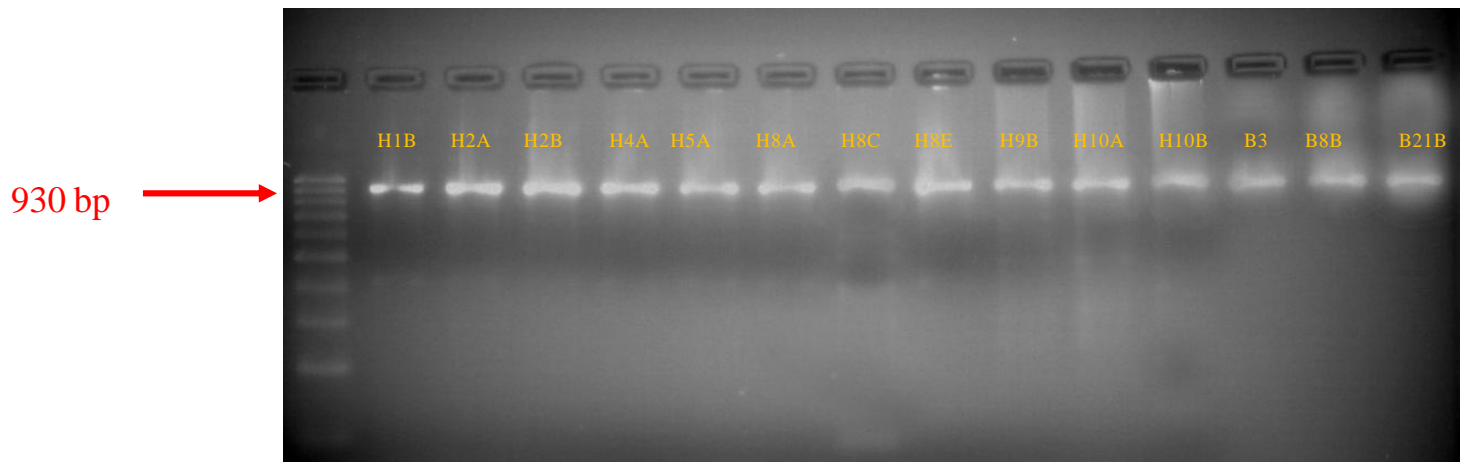

Fig.3 Amplification of nifH gene from genomic DNA of pigeon pea rhizobial isolates using Ueda et al., 1995 primers

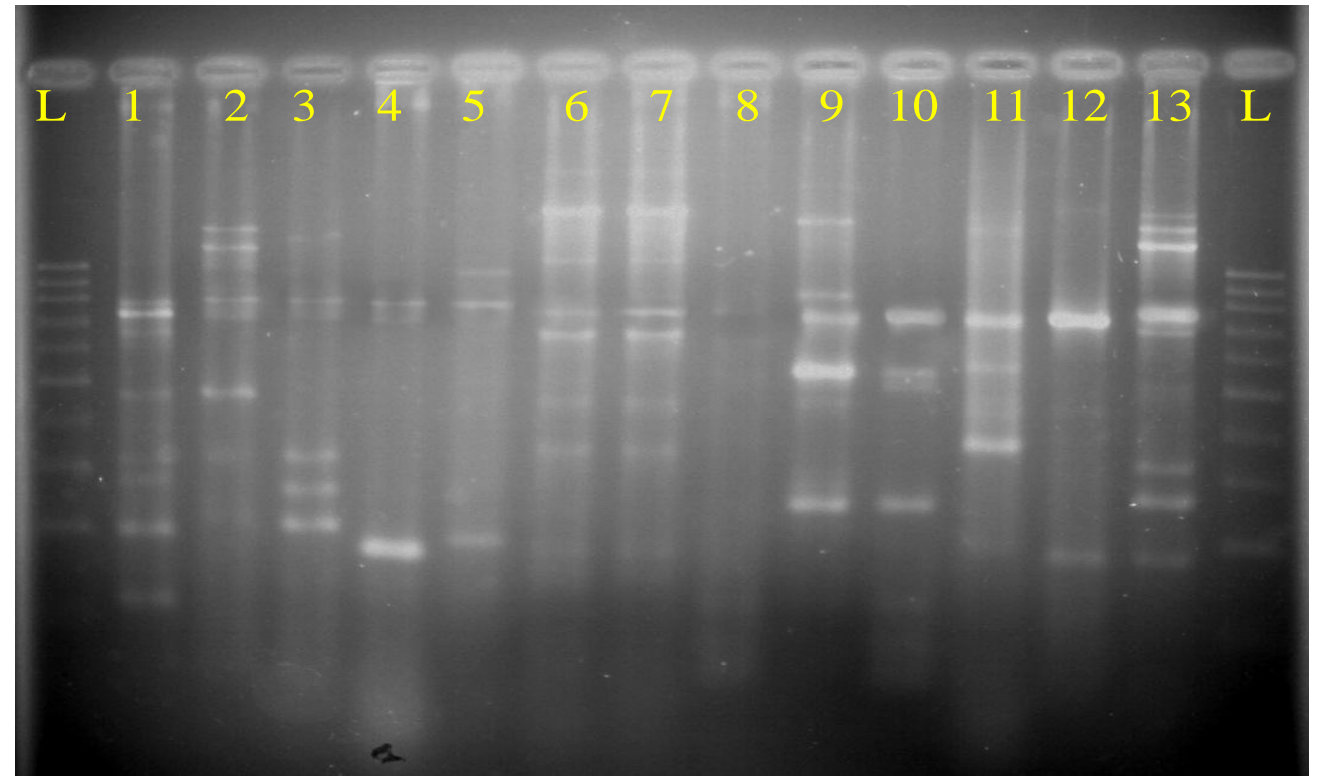


Fig.4 Amplification of 16S rDNA gene from genomic DNA of pigeon pea rhizobial isolates

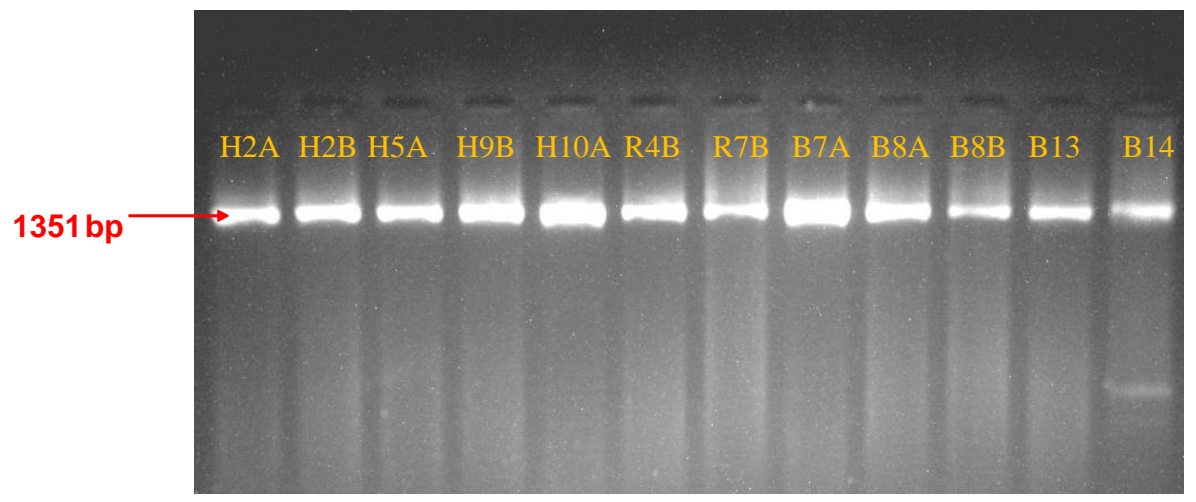

Fig.5 Banding pattern of amplified 16S rDNA gene product with restriction enzyme MspI

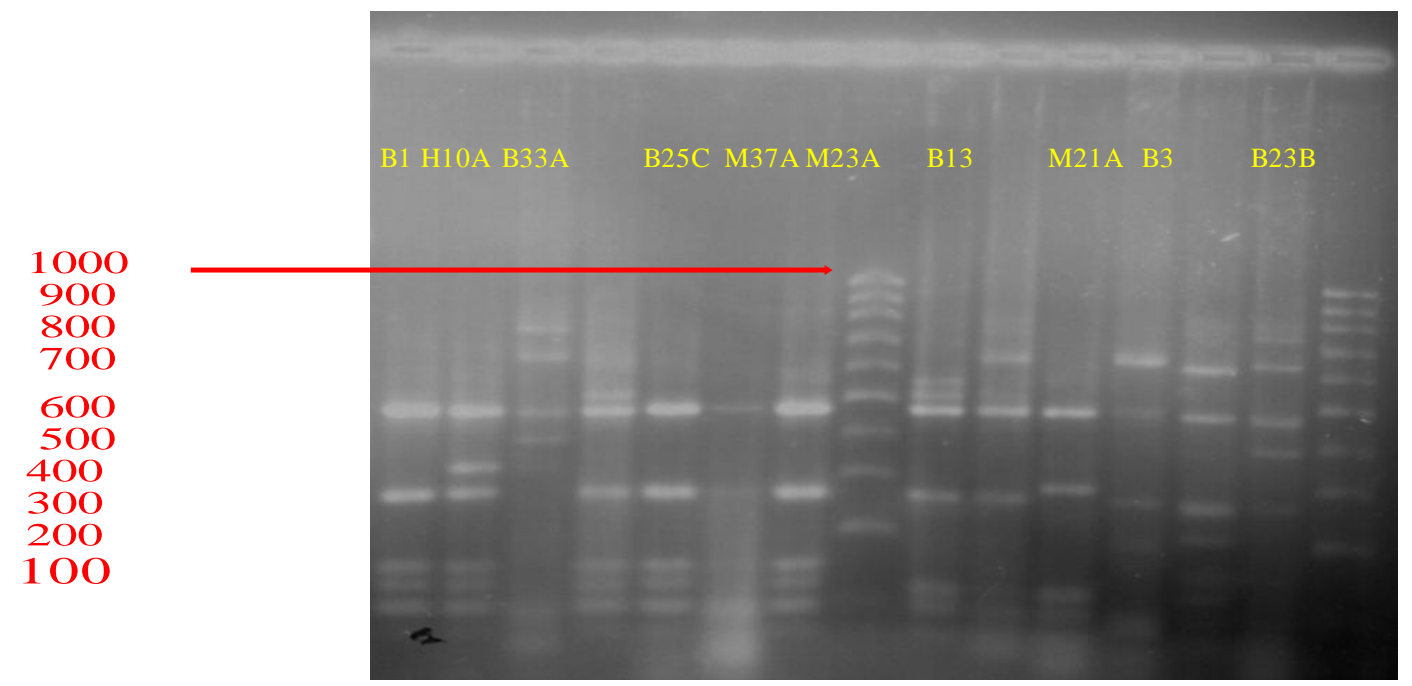

Fig.6 Banding pattern of amplified 16S rDNA gene product with restriction enzyme HaeIII

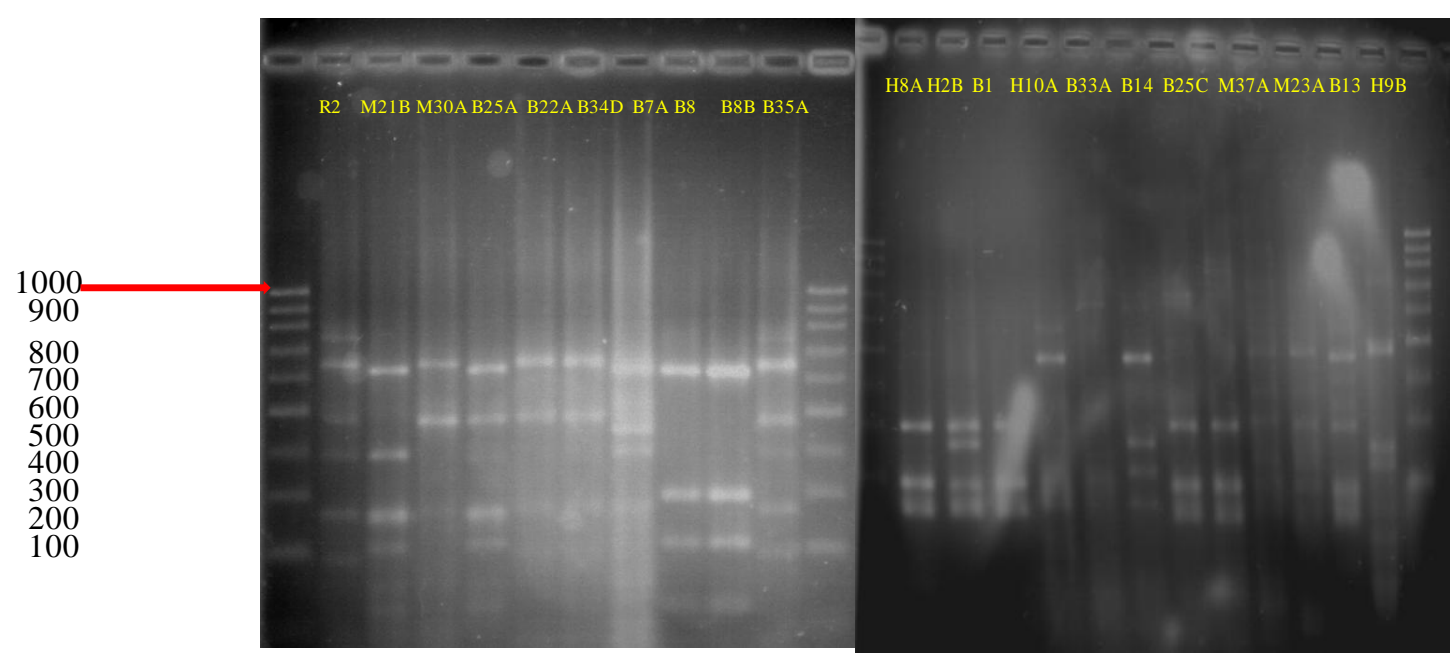


Fig.7 Dendrogram depicting grouping of pigeon pea rhizobial isolates by using MspI enzyme

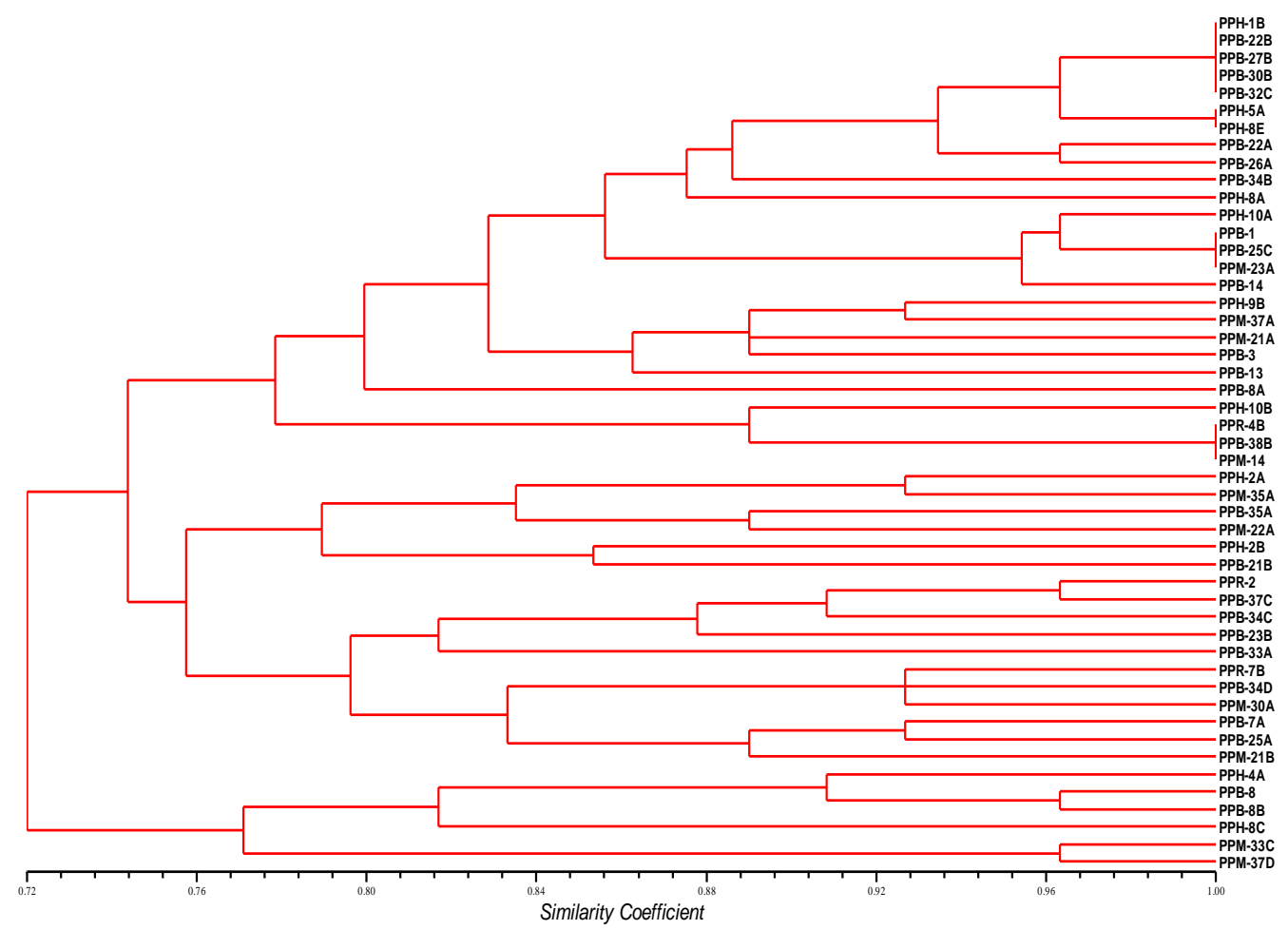

Fig.8 Dendrogram depicting grouping of pigeon pea rhizobial isolates by using HaeIII enzyme

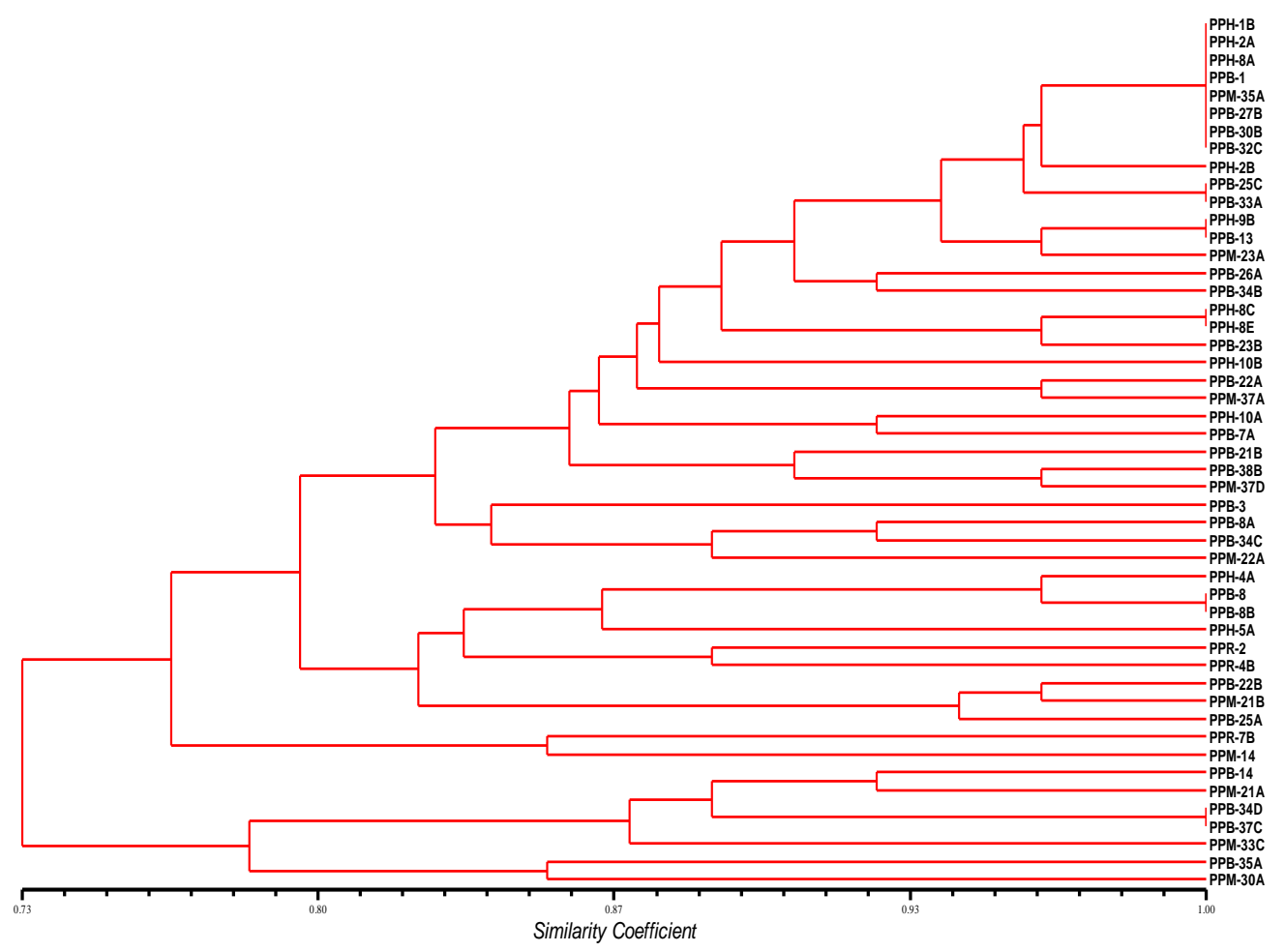


Fig.9 Combined Dendrogram based on the RFLP analysis of PCR-amplified 16S rRNA genes of pigeon pea rhizobial isolates by using $M s p I$ and HaeIII restriction enzyme

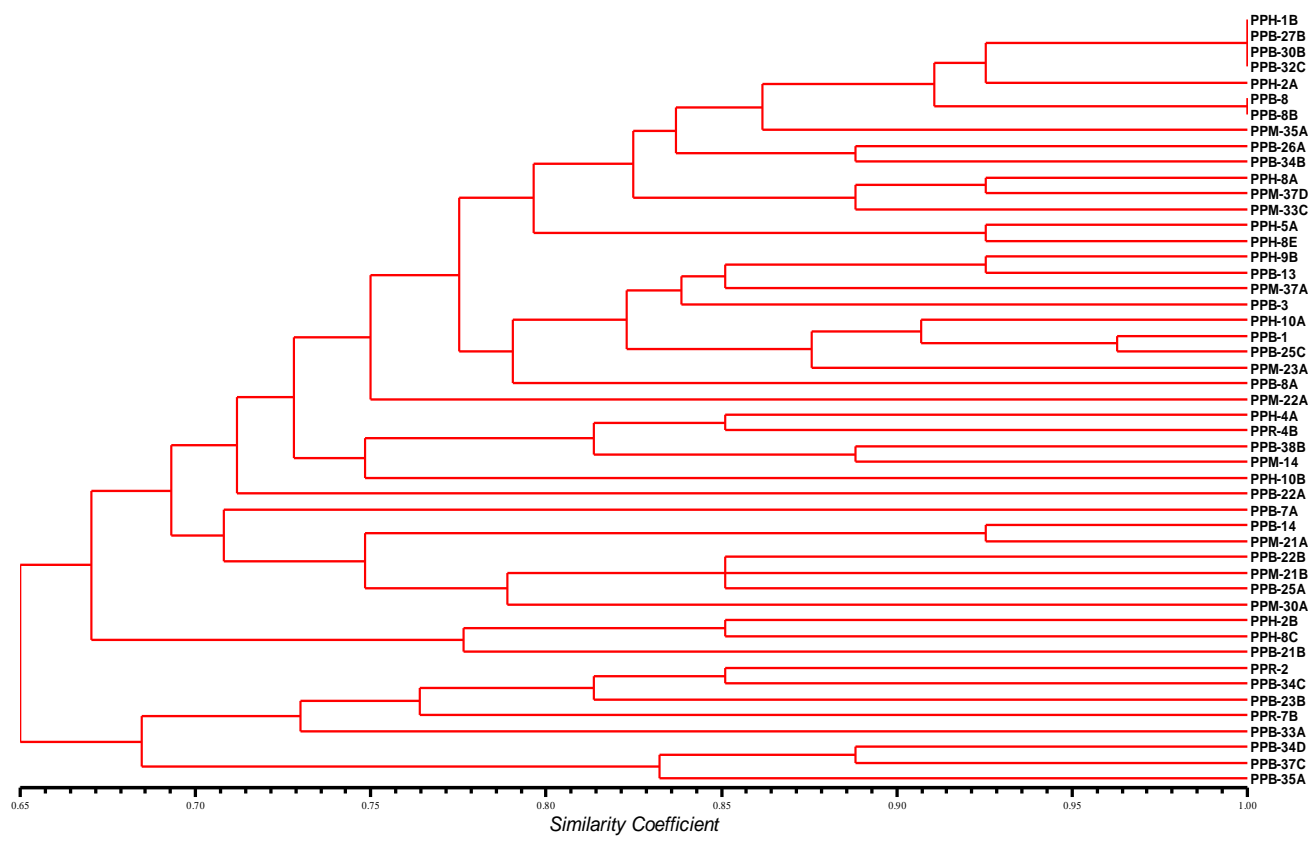

Fig.10 16S rRNA-based dendrogram showing the phylogenetic relationships among eight selected diazotrophic bacterial strains represented by diamonds and of other species of several genera used as reference. Phylogenies were inferred using the neighbor-joining method and trees

were generated using MEGA4 software. Numbers in parentheses represent the sequence accession numbers in GenBank database. Numbers at branch points indicate bootstrap values obtained with 1,000 replicates. The scale bar represents a

$2 \%$ estimated difference in nucleotide sequence

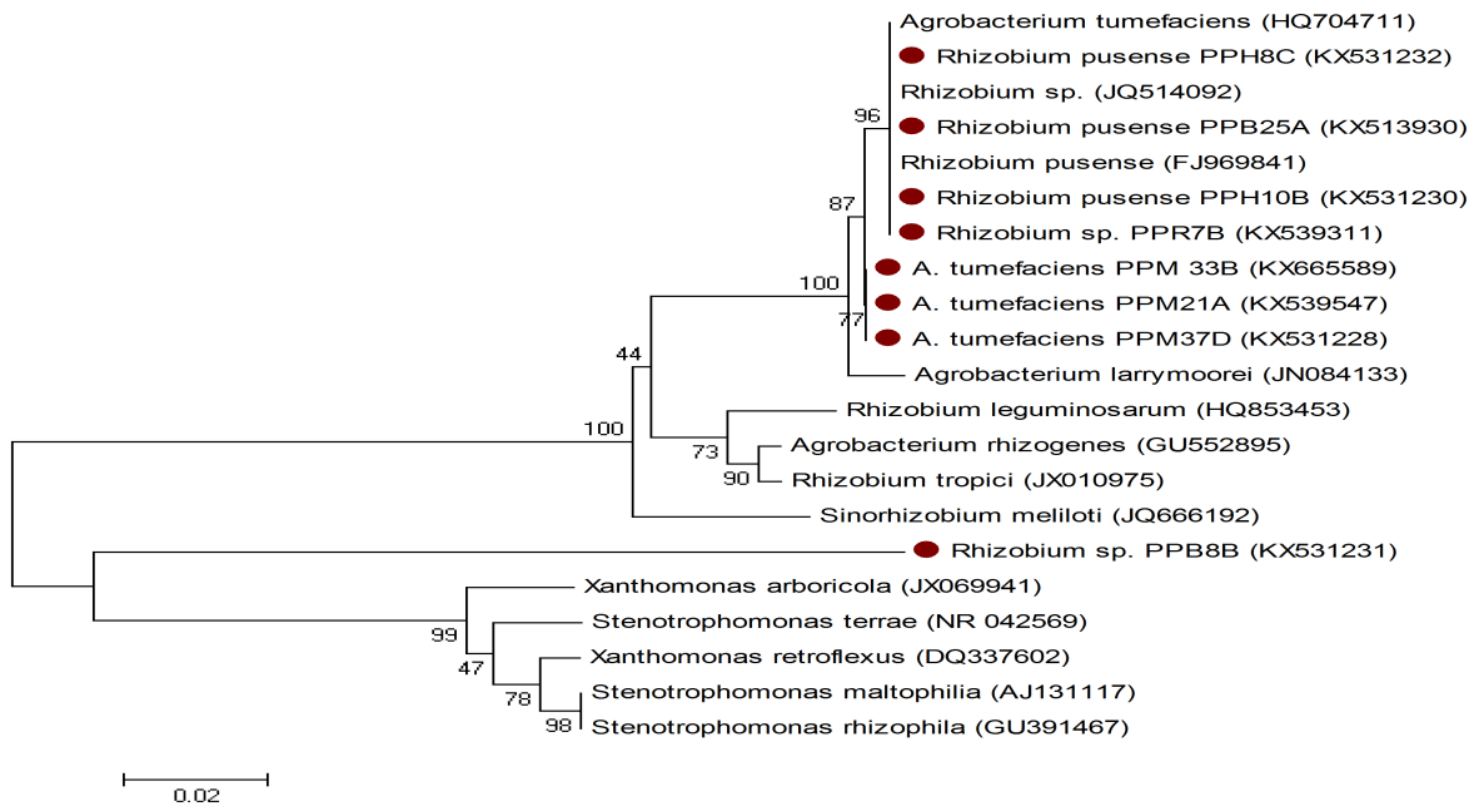


Subgroup II was having 17 isolates viz., PPH2A, PPM-35A, PPM-22A, PPH-2B, PPB21B, PPR-2, PPB-37C, PPB-34C, PPB-23B, PPB-33A, PPR-7B, PPB-34D, PPM-30A, PPB-7A, PPB-25A and PPM-21B, while rest of the isolates of major group I were in subgroup I. In major group I, most of the isolates viz., $\mathrm{PPH}-1 \mathrm{~B}, \mathrm{PPB}-22 \mathrm{~B}, \mathrm{PPB}-27 \mathrm{~B}$, PPB-30B, PPB-32C; PPH-5A, PPH-8E; PPB1, PPB-25C, PPM-23A; PPR-4B, PPB-38B and PPM-14 showed $100 \%$ similarity to each other which include the isolates obtained from same or different districts. Similarly, Moschetti et al., (2005) reported that RFLPPCR of $16 \mathrm{~S}$ rDNA analysis confirmed genotypes from those of the reference strains of $R$. Leguminosarum bv. viciae. Sklarz et al., (2009) also reported that ARDRA was performed in silico on 48,759 sequences from the Ribosomal Database Project and it was found that the fragmentation profiles were not necessarily unique for each sequence in the database, resulting in different species sharing fragmentation profiles. The average similarity between the sequence and ARDRA based clusters was $2.9 \%$, while the maximum similarity was 7.3\%.Similarly Sikora and Redzepovic (2003) reported that PCR-RFLP of $16 \mathrm{~S}$ rDNA clearly showed the existence of two divergent groups among indigenous Bradyrhizobia isolated from soybean nodules. Marinkovic et al., (2013) reported that RAPD analysis, using AP10, BC318, AF14 and SPH1 primers, indicated genetic differences between Bradyrhizobium strains. Armas et al., (2014) also reported that 16S-RFLP grouped the isolates within the Mesorhizobium genus and distinguished nine different ribotypes.

\section{Restriction fragment length polymorphism (RFLP) by using restriction enzyme HaeIII}

In this study, HaeIII restriction enzyme was used to digest the amplified $16 \mathrm{~S}$ rDNA fragment, which resulted in polymorphic bands. The product size of different bands varied from 50bp to 900bp (Figure 6). The dendrogram obtained from restriction analysis with HaeIII enzyme also resulted in formation of two major groups and the divergence among them was started at $73 \%$ similarity coefficient (Figure 8). The major group II has only seven rhizobial isolate viz., PPB-14, PPM-21A，PPB-34D， PPB-37C, PPM-33B, PPB-35A and PPM-30A in which two rhizobial isolates (PPB-34D and PPB-37C) showed $100 \%$ similarity so they are different from all other 42 pigeon pea rhizobial isolates present in major group I. Major group I was further divided into two subgroups at $77 \%$ level of similarity coefficient. Subgroup II was having PPR-7B and PPM-14 while rest of the isolates of major group I were in subgroup I. Isolates PPH-1B, PPH-2A, PPH-8A, PPB1, PPM-35A, PPB-27B, PPB-30B and PPB$32 \mathrm{C}$ showed $100 \%$ similarity and the same case was with ; PPB-25C, PPB-33A; PPH-9B, PPB-13; PPH-8C, PPH-8E; PPB-8 and PPB$8 \mathrm{~B}$ which were isolated from different areas of South-Western parts of Haryana (Figure 8). Deng et al., (2008) reported that amplified ribosomal DNA restriction analysis (ARDRA) is a commonly used tool to study microbial diversity that relies on DNA polymorphism. Studies by Appunu et al., (2008) revealed eight haplotypes of soybean Bradyrhizobia in India based on PCRrestriction fragment length polymorphism (RFLP) analysis of 16S rRNA and intergenic spacer (IGS) region between $16 \mathrm{~S}$ and $23 \mathrm{~S}$ rRNA. Ren et al., (2011) reported that seven Rhizobium strains associated with various legume species grown in different geographical regions of China were defined into four genomic groups related to Rhizobium giardinii based upon ribosomal intergenic spacer RFLP, phylogenies of $16 \mathrm{~S}$ rRNA and housekeeping genes and DNA relatedness. Rai et al., (2012) reported on molecular profiling of 28 indigenous rhizobial isolates obtained from different chickpea 
growing regions in peninsular and northern India by $16 \mathrm{~S}$ ribosomal DNA Restriction Fragment Length Polymorphism (RFLP) revealed three clusters at $67 \%$ similarity level. Similarly, Garg et al., (2016) reported that Dendrogram based on RFLP using HaeIII restriction enzyme of $16 \mathrm{~S}$ rDNA profiles from 29 isolates of berseem (Trifolium alexandrinum L.) were distributed in two major groups with different subgroups. A total of 7 biotypes were formed at $80 \%$ level of similarity by considering each cluster as rhizobial biotype.

\section{Restriction fragment length polymorphism (RFLP) by using MspI and HaeIII}

The analysis of the combined data with both the restriction enzymes i.e. MspI and HaeIII using NTSYS-PC software resulted in more diversification of the rhizobial isolates as shown in dendrogram (Figure 9). It is observed that all the isolates are distributed into two major groups and divergence among them is started at $65 \%$ similarity coefficient. Only eight isolates i.e. PPR-2, PPB-34C, PPB-23B， PPR-7B， PPB-33A， PPB-34D, PPB37C and PPB-35A which was present in major group II. Rest of the 41 rhizobial isolates present in major group I.

Major group I was further divided into two subgroups at $67 \%$ level of similarity coefficient. Subgroup II was having PPH-2B, PPH-8C and PPB-21B while rest of the isolates of major group I were in subgroup $\mathrm{I}$. Isolates PPH-1B, PPB-27B, PPB-30B and PPB-32C; PPB-8 and PPB-8B showed 100\% similarity which were isolated from different field. All the 49 rhizobial isolates at $80 \%$ level of similarity could be grouped into 18 different biotypes. The overall topology of this dendrogram is very similar to that of phylogram generated on the basis of RFLP of $16 \mathrm{~S}$ rDNA which presents the close phylogenetic relationship of A. glycyphyllos symbionts with the genus Mesorhizobium species (Gnat et al., 2014). Similarly large number of groups and further subgroups of rhizobia infecting different legumes have been reported (Duodu et al., 2005; Duodu et al., 2007; Dudeja and Singh, 2008; Kundu and Dudeja, 2008; Nandwani and Dudeja, 2009). Geographical effects on rhizobial diversity have also been reported (Handley et al., 1998; Grange and Hungria, 2004; Blazinkov et al., 2007).

There are several reports on the molecular diversity and biogeography of soybean rhizobia have published (Vinuesa et al., 2008; Li et al., 2011; Zhang et al., 2011; Adhikari et al., 2012; Qi et al., 2012), including a report on soybean rhizobia in Indian soils (Appunu et al., 2008). Similarly, Wadhwa et al., (2011) reported that Dendrogram based on RFLP of 16SrDNA of 54 rhizobia from five pea cultivars showed the formation of 13 subclusters at $80 \%$ level of similarity. Suneja et al., (2016) also reported on 43 rhizobial isolates from revertant of non-nodulating cultivar and 8 rhizobial isolates from normal nodulating cultivar of chickpea. A combined dendrogram of all the mesorhizobial isolates from the two cultivars showed two clusters at $70 \%$ similarity and eight subclusters at $80 \%$ similarity level.

\section{Genbank accession numbers}

The 16S rDNA gene sequences of the eight rhizobial strains were deposited in the National Center for Biotechnology Information (NCBI) GenBank database and accession number obtained (Table 3 and Figure 10).

Nearest identities of the strains were obtained by comparing sequences of the isolated 16SrRNA gene with available sequences in GenBank (http://www.ncbi.nlm.nih.gov/) using the BLASTn program. 


\section{Phylogenetic analysis}

RFLP analysis of 16S rDNA of rhizobial isolates from pigeon pea nodules using $M s p \mathrm{I}$ and HaeIII showed wide diversity among themselves. Dendrogram based on 16S rDNA profiles showed that the rhizobial isolates formed two major groups with different subgroups and the divergence among them started at 72,73 and $65 \%$ level of similarity coefficient with MspI and HaeIII bothrestriction enzymes.

At $80 \%$ level of similarity coefficient, 18 different biotypes were formed and out of these, isolates belonging to biotypes $13^{\text {th }}$ were most prevalent, which prevails in all the four districts studied. Eight isolates namely PPB8B, PPB-25A, PPH-8C, PPH-10B, PPM-21A, PPM-33B, PPM-37D and PPR-7B were selected as most efficient pigeon pea rhizobial isolates on the basis of molecular characterization. Similarly, Wolde-meskel et al., (2005) reported diversity within 195 rhizobial strains isolated from root nodules of 18 agroforestry species growing in diverse ecoclimatic zones in southern Ethiopia was investigated by using PCR-RFLP of the ribosomal operon. UPGMA dendrograms generated from cluster analyses of the $16 \mathrm{~S}$ and 23S rRNAgene PCR-RFLP data were in good agreement, and the combined distance matrices delineated87 genotypes, indicating considerable genetic diversity among the isolates. Yadav et al., (2013) also reported on molecular diversity studies of 19 rhizobia isolates from chickpea were conducted using simple sequence repeats (SSR) and $16 \mathrm{~S}$ rDNA-RFLP markers. These isolates were identified as different strains of Mesorhizobium, Rhizobium, Bradyrhizobium and Agrobacterium. Similarly, Msaddak et al., (2017) studied genetic diversity of 50 bacterial isolates nodulating Lupinus micranthus in five geographical sites from northern Tunisia was examined.
To conclude, ARDRA can be a suitable tool for genus differentiation of pigeon pea rhizobial strains. The dendrograms derived from PCR-RFLP (Figure 7, 8 and 9) and this consistency provided confidence that strain grouping reflected true relationships among rhizobial strains tested. By using metabolic and several modern molecular biological methodologies, we identified 8 rhizobial strains within 49 with special feature. So, all these selected pigeon pea rhizobial isolates should be further evaluated for their potentials under unsterilized conditions and field trial should be recomended.

Phylogenetic analyses of the selected ten rhizobial strains based on the neighborjoining (NJ) method with 1,000 bootstrap sampling resulted in two phylogenetically distinct groups (Fig. 10; represented by diamonds). It has been observed in our experiments that a significant diversity occurred among the eight selected diazotrophic isolates which enhanced growth and yield of pigeon pea plant under pot house conditions due to multiple PGP traits. Thus, the bacterial isolate which has multiple traits that result in plant growth promotion is more likely to be a successful inoculant strain. The selected bacterial isolates were sequenced through 16S rDNA and identified with online BLAST. Out of eight identified isolates, five belong to the group of Rhizobium and three from Agrobacterium. Overall, these potential diazotrophic strains will ultimately help in the development of biofertilizers for use in arid and semi-arid soils to increase the availability of nutrient and to enhance crop yield of pigeon pea.

\section{Acknowledgement}

We thank the department of Microbiology, CCS Haryana Agricultural University, Hisar, India for providing necessary facilities for this work. 


\section{References}

Adhikari D, Kaneto M, Itoh K, Suyama K, Pokharel BB, Gaihre YK (2012) Genetic diversity of soybean-nodulating rhizobia in Nepal in relation to climate and soil properties. Plant Soil. 357:131-145.

Ali S.F, Rawat LS, Meghvansi MK, Mahna SK (2009) Selection of stress-tolerant rhizobial isolates of wild legumes growing in dry regions of Rajasthan, India. ARPN J. Agric. Biol. Sci. 4(1):13-18

Anonymous (2011) Indian Agriculture. Ministry of Agriculture, India: 180-182pp

Ansari PG, Rao DLN (2014) Soybean Rhizobia in Indian Soils: Populations, host specificity and competitiveness. Proc. Natl. Acad. Sci., India, Sect. B Biol. Sci. 84:457-464

Ansari PG, Rao DLN, Pal KK (2014) Diversity and phylogeny of soybean rhizobia in central India. Ann. Microbiol. 64:15531565 .

Appunu C, Angele N, Laguerre G (2008) Genetic diversity of native bradyrhizobia isolated from soybeans (Glycine max L.) in different agricultural ecological climatic regions of India. Appl Environ Microbiol. 74:59915996.

Appunu C, NZoue A, Laguerre G (2008) Genetic diversity of native Bradyrhizobia isolated from Soybeans (Glycine max L.) in different agricultural ecological climatic regions of India. Appl. Environ. Microbiol. 74(19):5991-5996

Berrada H, Fikri-Benbrahim K (2014) Taxonomy of the Rhizobia: current perspectives. Brit Microbiol Res J. 4:616-639

Berrada H, Nouioui I, Houssaini MI, Ghachtouli NEL, Gtari M, Benbrahim KF (2012) Phenotypic and genotypic characterizations of rhizobia isolated from root nodules of multiple legume species native of Fez, Morocco. Afr. J. Microbiol. Res. 6(25): 5314-5324.

Blazinkov M, Sikora S, Uher D, Macesic D, Redzepovic S (2007) Genotypic characterization of indigenous Rhizobium leguminosarumbv. viciae field population in Croatia. Agric. Conspec. Sci. 72(2):153158.
Capote AN, PYepez AJ, Hidalgo MP, Machado $\mathrm{GV}$, Aguilar DAM, Velázquez E, Barrios LM (2014) Core and symbiotic genes reveal nine Mesorhizobium genospecies and three symbiotic lineages among the rhizobia nodulating Cicer canariense in its natural habitat (La Palma, Canary Islands).Syst. Appl. Microbiol. 37(2):140-8

Deng W, Xi D, Mao H, Wanapat M (2008) The use of molecular techniques based on ribosomal RNA and DNA for rumen microbial ecosystem studies: A review. Mol. Biol. Rep. 35:265-274

Dhull S, Gera R (2017) Assessing stress tolerant rhizobial isolates of Clusterbean (Cyamopsistetragonoloba (L.) Taub.) retrieved from semi-arid regions of Haryana, India. Int. J. Curr. Microbiol. Appl. Sci. 6:744-753.

Doignon-Bourcier F, Willems A, Coopman R, Laguerre G, Gillis M, De Lajudie P (2000) Genotypic characterization of Bradyrhizobium strains nodulating small senegalese legumes by $16 \mathrm{~S}-23 \mathrm{~S}$ rRNA intergenic gene spacers and amplified fragment length polymorphism fingerprint analyses. Appl. Environ. Microbiol. 66 (9):3987-3997.

Dubey RC, Maheshwari DK, Kumar H, Choure K (2010) Assessment of diversity and plant growth promoting attributes of rhizobia isolated from Cajanus cajan L. Afr. J. Biotechnol. 9(50):8619-8629.

Dudeja SS, Singh PC (2008) High and low nodulation in relation to molecular diversity of chickpea mesorhizobia in Indian soils. Arch. Agron. Soil Sci. 54(1):109-120.

Duodu S, Bhuvaneswari TV, Gudmundsson J, Svenning MM (2005) Symbiotic and saprophytic survival of three unmarked Rhizobium leguminosarum biovar trifoliis trains introduced into the field. Environ. Microbiol. 7(7):1049-1058.

Duodu S, Carlsson G, Huss-Danell K, Svenning MM (2007) Large genotypic variation but small variation in $\mathrm{N}_{2}$ fixation among rhizobia nodulating red clover in soils of Northern Scandinavia. J. Appl. Microbiol. 102(6):1625-1635.

Echeverrigaray S, Toreson SP, Carrau JL (2000) RAPD marker polymorphism among 
commercial winery yeast strains. World $J$. Microbiol. Biotech. 16:143-146.

El-Fiki AA (2006) Genetic diversity in rhizobia determined by random amplified polymorphic DNA analysis. J. Agri. Soc. Sci. 2(1):1-4.

Garg V, Kukreja K, Gera R (2016) Molecular diversity of Berseem (Trifolium alexandrinum L.) rhizobia isolated from Haryana soil. Legume Res. 39:729-733.

Gera R, Kumar V, Shekhawat K (2014) Genotypic diversity of native population of rhizobia nodulating Vicia faba plants in arid and semi-arid regions of Haryana (India). Ann. Microbiol. 64:619-626.

Gnat S, Wojcik M, Wdowiak-Wróbel S, Kalita M, Ptaszyńska A, Małek W (2014) Phenotypic characterization of Astragalus glycyphyllos symbionts and their phylogeny based on the $16 \mathrm{~S}$ rDNA sequences and RFLP of $16 \mathrm{~S}$ rRNA gene. Antonie Leeuwenhoek. 105:1033-1048

Grange L, Hungria M (2004) Genetic diversity of indigenous common bean (Phaseolus vulgaris) rhizobia in two Brazilian ecosystems. Soil Biol. Biochem.36(9):13891398.

Gray EJ, Smith DL (2005) Intracellular and extracellular PGPR: commonalities and distinctions in the plant-bacterium signaling processes. Soil BiolBiochem. 37:395-412

Handley BA, Hedges AJ, Beringer JE (1998) Importance of host plants for detecting the population diversity of Rhizobium leguminosarum biovarviciae in soil. Soil Biol. Biochem. 30(2):231-275.

HeleneLCF, Delamuta JRM, Ribeiro RA , HungriaM (2017) Bradyrhizobium mercantei sp. nov., a nitrogen-fixing symbiont isolated from nodules of Degueliacostata (syn. Lonchocarpuscost atus). Int. J. Syst. Evol. Microbiol. 67:18271834.

Joshi PK, Parthasarathy Rao P, Gowda CLL, Jones R, Silim SN, Saxena KB, Kumar J (2001) The world chickpea and pigeonpea economies: facts, trends and outlook. Patancheru, India: ICRISAT. $62 \mathrm{pp}$.

Josic D, Popovic V, Mladenovic Drinic S, Konstatinov K (2002) Biodiversity among indigenous $R$. leguminosarum bv. trifolii. 17th World Congress Soil Sciences, 14-21 August 2002, Thailand, CD ROM: 10332(6)

Kayasth M, Gera R, Dudeja SS, Sharma PK, Kumar V (2014a) Studies on salinization in Haryana soils on free-living nitrogen-fixing bacterial populations and their activity. $J$. Basic Microbiol. 54:170-179.

Kayasth M, Kumar V, Gera R (2014b) Gordonia sp.: a salt tolerant bacterial inoculant for growth promotion of pearl millet under saline soil conditions. 3 Biotech 4:553-557.

Kepner KA, Barger EL, Roy B (1987) Principles of farm machinery. The AVI Publ. Co. Inc. New York. 298-324pp.

Khoury CK, Castaneda-Alvarez NP, Achicanoy HA, Sosa CC, Bernau V, Kassa MT, Norton SL, Maesen LJG, Upadhyaya HD, Ramírez-Villegas J, Jarvis A, Struik PC (2015) Crop wild relatives of pigeon pea [Cajanus cajan (L.) Millsp.]: Distributions, exsitu conservation status, and potential genetic resources for abiotic stress tolerance. Biological Conservation. 184:259-270.

Koskey G, Mburul SW, Njerul EM, Kimiti JM, Ombori O, Maingi JM (2017) Potential of Native Rhizobia in Enhancing Nitrogen Fixation and Yields of Climbing Beans (Phaseolus vulgaris L.) in Contrasting Environments of Eastern Kenya. Front Plant Sci. 8:443

Kuldeep, Gera R, Padder SA (2016) Evaluation of rhizobial strains for abiotic stress tolerance in pigeon pea from arid and semi-arid zones of Haryana, India. The Ecoscan. 9:401-407.

Kumar V, Gera R (2014) Isolation of a multi-trait plant growth promoting Brevundimonas sp. and its effect on the growth of Bt-cotton. 3 Biotech 4:97-101.

Kumar V, Kayasth M, Chaudhary V, Gera R (2014) Diversity of diazotrophs in arid and semi-arid regions of Haryana and evaluation of their plant growth promoting potential on Bt-cotton and pearl millet. Ann. Microbiol. 64:1301-1313.

Kundu S, Dudeja SS (2008) Molecular diversity, effectiveness and competitiveness of indigenous rhizobial population infecting mungbean Vigna radiata (L.) Wilczek 
under semi-arid conditions. Ind. J. Microbiol. 48:445-452.

Kwon SW, Park JY, Kim JS, Kang JW, Cho YH (2005) Phylogenetic analysis of the genera Bradyrhizobium, Mesorhizobium, Rhizobium and Sinorhizobium on the basis of $16 \mathrm{~S}$ rRNA gene and internally transcribed spacer region sequences. Int. J. Syst. Evol. Microbiol. 55:263-270.

Laguerre G, Nour, SM, Macheret V, Sanjuan, J, Drouin P, Amarger N (2001) Classification of rhizobia based on $\operatorname{nod} \mathrm{C}$ and nifH gene analysis reveals a close phylogenetic relationship among Phaseolus vulgaris symbionts. Microbiol. 147:981-993.

Laranjo M, Rodrigues R, Alho L, Oliveria S (2001) Rhizobia of chickpea from Southern Portugal: Symbiotic efficiency and genetic diversity. J. Appl. Microbiol. 90:662-667.

Li QQ, Wang ET, Zhang YZ, Zhang YM, Tian CF, Sui XH, Chen WF, Chen WX (2011) Diversity and biogeography of rhizobia isolated from root nodules of Glycine max grown in Hebei province. China. Microb. Ecol. 61:917-931.

Lukow T, Dunfield PF, Liesack W (2000) Use of the t-RFLP technique to assess spatial and temporal changes in the bacterial community structure within an agricultural soil planted with transgenic and non transgenic potato plants. FEMS Microbial Ecol.32:241-247.

Mapfumes P (1993) Pigeon pea in Zimbabwe: A new crop with potential in soil fertility research for maize based farming systems in Malawi and Zimbabwe.

Marinkovic J, Djordjevic V, BalesevicTubic S, Bjelic D, Vucelic-Radovic B, Josic D (2013) Osmotic stress tolerance, PGP traits and RAPDanalysis of Brady rhizobium japonicum strains. Genetika. 45(1):75-86.

Matiru VN, Dakora FD (2004) Potential use of rhizobial bacteria as promoters of plant growth for increased yield in landraces of African cereal crops. Afr. J. Biotechnol. 3(1):1-7.

Mnasri B, Aouani ME, Mhamdi R (2007) Nodulation and growth of common bean (Phaseolus vulgaris) under water deficiency. Soil Biol. Biochem. 39:17441750 .
Mondal HK, Mehta S, Kaur H, Gera R (2017b) Characterization of stress tolerant mungbean rhizobia as PGPR and plant growth promotion under abiotic stress. Indian Journal of Ecology. 44:38-42.

Moschetti G, Peluso AL, Protopapa A, Anastasioa M, Pepea O, Defezb R (2005) Use of nodulation pattern, stress tolerance, nodC gene amplification, RAPD-PCR and RFLP$16 \mathrm{~S}$ rDNA analysis to discriminate genotypes of Rhizobium leguminosarum biovar viciae. Syst. Appl. Microbiol. 28:619-631.

Msaddak A, Duran D, Rejili M, Mars M, Argueso TR, Imperial J, Palacios J, Rey L (2017) Diverse Bacteria Affiliated with the Genera Microvirga, Phyllobacterium, and Bradyrhizobium Nodulate Lupinus micranthus Growing in Soils of Northern Tunisia. Appl. Environ. Microbiol. 83(6):113.

Muyzer G (1999) DGGE/TGGE a method for identifying genes from natural ecosystems. Curr. Opinion in Microbiol. 2(3):317-322.

Muyzer G, Smalla K (1998) Application of denaturing gradient gel electrophoresis (DGGE) and temperature gradient gel electrophoresis (TGGE) in microbial ecology. Antonie van Leeuwenhoek. J. Microbiol. Serol. 73:127-141.

Nandwani R, Dudeja SS (2009) Molecular diversity of a native mesorhizobial population chickpea (Cicer arientinum L.) in Indian soils. J. Basic Microbiol. 49(5):463-70.

Olivieri, Frank SA (1994) The Evolution of Nodulation in Rhizobium: Altruism in the rhizosphere. The J. of Heredity. 85(1):4647.

Perret X, Broughton WJ (1998) Rapid identification of Rhizobium strains by targeted PCR fingerprinting. Plant Soil. 204:21-34.

Perret X, Staehelin C, Broughton WJ (2000) Molecular basis of symbiotic promiscuity. Microbiol. Mol. Biol. Rev. 64:180-201.

Pini F, Galardini M, Bazzicalupo M, Mengoni A (2011). Plant bacteria association and symbiosis: Are there common genomic traits in alphaproteobacteria? Genes. 2:1017-1032 
Poupot R, Martinez RE, Gautier N, Promé JC (1995) Wild type Rhizobium etli, a bean symbiont, produces acetyl-fucosylated, $\mathrm{N}$ methylated, and carbamoylated nodulation factors. J. Biol. Chem.270:6050-6055.

Poupot R, Martinez RE, Prome JC (1993) Nodulation factors from Rhizobium tropici are sulfated or non-sulfated chitopentasaccharides containing an $\mathrm{N}$ methyl-N-acylglucosamine terminus. Biochemistry32:10430-10435.

Qi WJ, He DH, Xia ZJ, Dai MX (2012) Research on biological characteristics and genetic diversity of rhizobia of Glycine soja in the Yellow River delta. Shandong Sci. 25:3237.

Rai R, Dash PK, Mohapatra T, Singh A (2012)Phenotypic and molecular characterization of indigenous rhizobia nodulating chickpea in India.Indian J. Exp. Biol. 50(5):340-50.

Rajasundari K, Ilamurugu K, Logeshwaran P (2009) Genetic diversity in rhizobial isolates determined by RAPDs. Afr. $J$. Biotechnol. 8(12):2677-2681.

Rao DLN (2013) Soil biological health and its management. In: Soil health management: productivity sustainability-resource management, pp 55-83. H.L. S.Tandon (Ed.), FDCO, New Delhi.

Ren DW, Wang ET, Chen WF, Sui XH, Zhang XX, Liu HC, Chen WX (2011) Rhizobium herbae sp. nov. and Rhizobium giardinii related bacteria, minor microsymbionts of various wild legumes in China. Int. J. Syst. Evol. Microbiol. 61:1912-1920.

Rohlf FJ (1998) On application of geometric morphometrics to studies of ontogeny and phylogeny. Syst. Biol. 47:147-158.

Sambrook J, Russell DW (2001) Molecular cloning: A laboratory manual. Cold spring harbor laboratory press, Cold spring harbor, NY.

Sawada H, Kuykendall LD, Young JM (2003) Changing concepts in the systematics of bacterial nitrogen-fixing legume symbionts. J. Gen. Appl. Microbiol. 49:155-179.

Shamseldin A, Abdelkhalek A, Sadowsky MJ (2017) Recent changes to the classification of symbiotic, nitrogen-fixing, legume- associating bacteria: a review. Symbiosis. 71:91-109.

Sikora S, Redzepovic S. (2003) Genotypic characterisation of indigenous Soybean Rhizobia by PCR-RFLP of $16 S$ rDNA, repPCR and RAPD analysis. Food Technol. Biotechnol. 41(1) 61-67.

Silva K, Florentino LA, Silva KB, Vandamme P, Mariade F, Moreira S (2012) Cupriavidusnecator isolates are able to fix nitrogen in symbiosis with different legume species.SystApplMicrobiol. 35(3):175-182.

Sklarz MY, Angel R, Gillor O, Ines M, Soares M (2009) Evaluating amplified rDNA restriction analysis assay for identification of bacterial communities. Antonie Leeuwenhoek. 96:659-664.

Snapp SS, Rohrbach DD, Simtowe F, Freeman HA (2002) Sustainable soil management options for Malawi: can smallholder farmers grow more legumes? AgricEcosyst Environ. 91:159-174.

Sofie E, Meyer D, Cnockaert M, Ardley JK, Wyk BEV, Vandamme PA, Howieson JG (2014) Burkholderia dilworthii sp. nov., isolated from Lebeckia ambigua root nodules. Int. J. Syst. Evol. Microbiol. 64:1090-1095.

Suneja P, Piplani S, Dahiya P, Dudeja SS (2016) Molecular characterization of rhizobia from revertants of non-nodulating cultivar and normal cultivar of chickpea. J. Agr. Sci. Tech.18:763-773.

Swelim DM, Hashem FM, Kuykendall LD, Hegazi NI, Abdel-Wahab SM (1997) Host specificity and phenotypic diversity of Rhizobium strains nodulatingLeucaena, Acacia and Sesbenia in Egypt. Biol. Fertil. Soils23(3):224-232.

Tan Z, Hurek T, Vinuesa P, Muller P, Ladha JK, Reinhold-Hurek B (2001) Specific detection of Bradyrhizobium and Rhizobium strains colonizing rice (Oryza sativa) roots by $16 \mathrm{~S}-23 \mathrm{~S}$ ribosomal DNA intergenic spacer targeted PCR. Appl. Environ. Microbiol. 67(8):3655-3664.

Ueda T, Suga Y, Yahiro N, Matsuguchi T (1995) Remarkable $\mathrm{N}_{2}$-fixing bacterial diversity detected in rice roots by molecular evolutionary analysis of nifH gene sequences. J. Bacteriol. 177:1414-1417. 
Vincent JM (1970) A Manual for the practical study of root nodule bacteria.IBP handbook, no. 15. Blackwell scientific publications, Ltd, Oxford, England.

Vinuesa P, Rademaker LW, Debrujin FJ, Werner D (1998) Genotypic characterization of Bradyrhizobium strains nodulating endemic woody legumes of the Canary Islands by PCR-restriction fragment length polymorphism analysis of genes encoding $16 \mathrm{~S}$ rRNA (16S rDNA) and 16S-23S rDNAintergenic spacers, repetitive extragenic palindromic PCR genomic fingerprinting, and partial $16 \mathrm{~S}$ rDNA sequencing. Appl. Environ. Microbiol. 64(6):2096-2104.

Vinuesa P, Rojas-Jimenez K, Contreras-Moreira B, Mahna SK, Prasad BN, Moe H, Selvaraju SB, Thierfelder $\mathrm{H}$, Werner $\mathrm{D}$ (2008) Multilocus sequence analysis for assessment of the biogeography and evolutionary genetics of four Bradyrhizobium species that nodulated soybeans on the Asiatic Continent. Appl. Environ. Microbiol. 74:6987-6996.

Wadhwa K, Dudeja SS, Yadav RK (2011) Molecular diversity of native rhizobia trapped by five field pea genotypes in Indian soils.J. Basic Microbiol.51:89-97.

Wolde-meskel E, Terefework Z, Frostegard A, Lindstrom K (2005) Genetic diversity and phylogeny of rhizobia isolated from agroforestry legume species in southern Ethiopia. Int. J. Syst. Evol. Microbiol. 55:1439-1452.

Wu KS, Traanksley SD (1993) Abundance, polymorphism and genetic mapping of microsatellites in rice. Mol. Genet. 241:225-235.

Yadav A, Singh AL, Rai GK, Singh M (2013) Assessment of molecular diversity in chickpea (Cicer arietinum L.) rhizobia and structural analysis of $16 \mathrm{~S}$ rDNA sequences from Mesorhizobium ciceri. Pol. J. Microbiol. 62(3):253-62.

Young JPW, Haukka KE (1996) Diversity and phylogeny of rhizobia. New Phytol. 133:8794

Zahran HH (2001) Rhizobia from wild legumes: diversity, taxonomy, ecology, nitrogen fixation and biotechnology. J. Biotechnol. 91:143-153.

Zehr JP, Capone DG (1996) Problems and promises of assaying the genetic potential for nitrogen fixation in the marine environment. Microbiol. Ecol. 32:263-281.

Zhang YM, Li Y Jr, Chen WF, Wang ET, Tian CF, Li QQ, Zhang YZ, Sui XH, Chen WX (2011) Biodiversity and biogeography of rhizobia associated with soybean plants grown in the north China plain. Appl. Environ. Microbiol. 77:6331-6342.

\section{How to cite this article:}

Kuldeep Singh, Subha Dhull and Rajesh Gera. 2018. Genetic Diversity of Diazotrophs Nodulating Pigeon Pea in Arid and Semi-Arid Zones of Haryana, India. Int.J.Curr.Microbiol.App.Sci. 7(03): 3447-3467. doi: https://doi.org/10.20546/ijcmas.2018.703.397 